\title{
Does Judaism Have Dogma? Moses Mendelssohn and a Pivotal Nineteenth-Century Debate
}

Dogmas serve important functions in religious communities. R. Marston Speight identifies several such functions, including (a) providing a basis for membership in the community; (b) testing for orthodoxy; (c) expressing communal self-understanding; and (d) affirming communal unity. ${ }^{1}$

Since the Middle Ages, Jewish thinkers have debated the question whether or not Judaism has dogma. ${ }^{2}$ Moses Mendelssohn launched the modern Jewish discussion of this question with what many interpreted to be a negative response to this question. In the first part of this essay, I will show how Mendelssohn's eighteenth-century discussion is informed by interreligious concerns; namely, seeking to express a distinct Jewish communal self-understanding in relation to Christianity. Mendelssohn rejects dogma in a Christian sense while affirming that there are principles that define Judaism analytically. In the second part of the essay, I will explore a pivotal nineteenthcentury debate over dogma in Judaism, in which the problem is addressed from an intrareligious perspective showing how it is informed by the problem of Jewish communal unity. ${ }^{3}$

My discussion will focus on four thinkers, each of whom was an outstanding representative of a major school of German Judaism: Mendelssohn, the leading figure of the Haskalah; Samson Raphael Hirsch, the ideological leader of German Neo-Ortho-

1 See R. Marston Speight, “Creeds: An Overview," in Encyclopedia of Religion, 2nd ed., ed. Lindsay Jones (Detroit: Macmillan 2004), 3:2053. Speight writes specifically about the function of creeds, which he defines as "confession[s] of faith, put into concise form, endowed with authority, and intended for general use in religious rites." See Speight, 2052. Given that creeds have confessional, liturgical roles, their functions are broader than dogmas. Nevertheless, there is a great deal of overlap between the functions of dogma and creed. In the nineteenth-century debate over dogma in Judaism that will be explored, some writers focus on creed.

2 Menachem Kellner has done more than anyone else to explore this topic. See Menachem Kellner, Dogma in Medieval Jewish Thought: From Maimonides to Abravanel (Oxford: Oxford University Press, 1986); Kellner, Must a Jew Believe Anything? 2nd ed. (Oxford and Portland, OR: Littman Library of Jewish Civilization, 2006). On Maimonides's account of dogma, see Marc B. Shapiro, The Limits of Orthodox Theology: Maimonides' Thirteen Principles Reappraised (Oxford and Portland, OR: Littman Library of Jewish Civilization, 2004); Louis Jacobs, Principles of the Jewish Faith: An Analytical Study (London: Vallentine Mitchell, 1964).

3 While scholars have largely forgotten the nineteenth-century debate over dogma in Judaism, the one exception is Kerstin von der Krone. See her brief treatment in von der Krone, "Jüdische Wissenschaft und modernes Judentum: eine Dogmendebatte," in Die "Wissenschaft des Judentums": Eine Bestandsaufnahme, ed. Thomas Meyer and Andreas Kilcher (Paderborn: Wilhelm Fink Verlag, 2015), 11820.

Ә OpenAccess. (c) 2020 Michah Gottlieb, published by De Gruyter. (cc) BY-NC-ND This work is licensed under the Creative Commons Attribution-NonCommercial-NoDerivatives 4.0 License. 
doxy; Manuel Joël, a leading figure in Positive-Historical Judaism, and Abraham Geiger, the intellectual leader of Reform Judaism. I will show how each author's discussion of dogma is informed by his concept of Judaism.

\section{Mendelssohn's Haskalah: Judaism as Non-Dogmatic Religion}

In an important 1926 article titled "Besitzt das überlieferte Judentum Dogmen?" (“Does Traditional Judaism Possess Dogmas?"), Leo Baeck refers to the "long and widely held belief" that for Mendelssohn, "Judaism was a religion without dogmas."4 The problem with this claim, Baeck notes, is that the term "dogma" is notoriously undefined. He observes that in the original Greek, "dogma" (dokein) has several meanings. In the Septuagint and the New Testament, it means "order" or "decree" and usually refers to governmental regulations. In ancient philosophy, dokein is used in a derivative sense to refer to intellectual axioms that were regarded as "decrees of cognition." According to Baeck, it was only when ancient philosophy joined Christianity that "dogma" came to refer to "statements of faith."5 Catholicism enumerated revealed doctrines found in sacred texts or traditions that were confirmed by an authoritative religious body as dogma. ${ }^{6}$ Affirming dogma was regarded as a divine commandment and a necessary condition for salvation, while denying it was deemed a heresy that would consign a person to eternal perdition. Baeck notes that Protestant theologians largely accepted their Catholic counterparts' understanding of dogma, ${ }^{7}$ and recent scholars have tended to affirm the general contours of Baeck's genealogy. ${ }^{8}$

\footnotetext{
4 Leo Baeck, "Does Traditional Judaism Possess Dogmas?” in Studies in Jewish Thought: An Anthol ogy of German Jewish Scholarship, ed. Alfred Jospe (Detroit: Wayne State University Press, 1981), 41. 5 Baeck, "Does Traditional Judaism Possess Dogmas?", 45. M. E. Williams notes that in ancient Greek, "dogma" (dokein) can also mean "private opinion" and that in early Christianity, it could refer both to particular teachings (e.g. the immortality of the soul) and to an entire system of teachings (e.g. Christian dogma as opposed to pagan dogma). See M.E. Williams, "Dogma," in New Catholic Encyclopedia, 2nd ed., ed. Thomas Carson (Detroit: Thomson/Gale, 2002), 1:810-11.

6 Baeck, “Does Traditional Judaism Possess Dogmas?”, 46-47.

7 Baeck notes that some Protestant theologians denied that Christianity had dogma because they denied the existence of infallible religious institutions to confirm it. See Baeck, 46. The relationship between Jewish thinkers such as Mendelssohn, Geiger, and Baeck who denied that Judaism had dogma and Protestant thinkers who denied that Christianity had dogma is an important subject that exceeds the bounds of this essay.

8 See Williams, "Dogma”; Adolf Darlap and Karl Rahner, "Dogma," in Encyclopedia of Religion, 2nd ed., ed. Lindsay Jones (Detroit: Macmillan, 2004), 4:2387-90.
} 
Despite the widely held view that Mendelssohn denied that Judaism has dogma, he never uses the term "dogma” in connection with Judaism. ${ }^{9}$ Mendelssohn's denial of dogma in Judaism is most commonly inferred from his distinction between revealed religion and revealed legislation. For Mendelssohn, revealed religion refers to revealed theological doctrines, while revealed legislation refers to revealed law. For Mendelssohn, Christianity is grounded in revealed religion, while Judaism only recognises revealed legislation. ${ }^{10}$

In Menachem Kellner's influential book Must a Jew Believe Anything? (first edition 1999; second edition 2006), he interprets Mendelssohn's distinction between revealed religion and revealed legislation as "orthopraxy." Kellner does not claim that Mendelssohn deems doctrines unimportant in Judaism. Rather, he contends that Mendelssohn interprets Judaism as comprising two elements: principles of universal natural religion known through reason (including God's existence and the immortality of the soul) and ritual laws specific to Jews known through revelation. Kellner criticises Mendelssohn's philosophy of Judaism as schizophrenic, splitting the Jew into a public human being and a private Jew. ${ }^{11}$ Kellner's interpretation of Mendelssohn has a long history. In 1840, the Reform theologian Solomon Ludwig Steinheim charged Mendelssohn with being "a heathen in his brain and a Jew in his body."12

This interpretation seriously misunderstands Mendelssohn for three reasons. First, Mendelssohn does not limit the doctrines at the core of Judaism to universal teachings of natural religion. In his 1783 Jerusalem, he asserts that Judaism comprises three elements: (a) universal eternal truths of natural religion, including God's existence, divine providence, the immortality of the soul, and natural morality, which

9 However, shortly after Mendelssohn's death in 1786, his disciple David Friedländer attributed this view to his teacher. In 1788, Friedländer wrote: “Among our great men, Mendelssohn was the first, not indeed to discover, but to emphasise and teach with full clarity that the distinguishing principle of Judaism is that we have no dogmas [wir keinen Dogmen], no articles of faith, no teachings about salvation that are indispensable and necessary for blessedness" (my emphasis). See David Friedländer, Der Prediger (Berlin: Friedrich Maurer, 1788), 23. I thank Uta Lohmann for calling my attention to this source.

10 See Moses Mendelssohn, Gesammelte Schriften: Jubiläumsausgabe, ed. Alexander Altmann et al. (Stuttgart and Bad Cannstatt: Frommann-Holzboog, 1971-), 8:164, 96 (henceforth: JubA); Mendelssohn, Jerusalem, or On Religious Power and Judaism, trans. Allan Arkush, ed. Alexander Altmann (Hanover, NH: University Press of New England, 1983), 97, 248; Mendelssohn, JubA, 7:90-102; Mendelssohn, Moses Mendelssohn: Writings on Judaism, Christianity, and the Bible, trans. Curtis Bowman, Elias Sacks, and Allan Arkush, ed. Michah Gottlieb (Hanover, NH: University Press of New England, 2011), 16-27.

11 See Kellner, Must a Jew Believe Anything?, 112, note 3. In claiming that Mendelssohn splits the Jew into a public human being and a private Jew, Kellner cites Yehuda Leib Gordon's famous expression (often mistakenly attributed to Mendelssohn): "Behave like a human being on the street, and like a Jew in your tent."

12 See Salomon Steinheim, Moses Mendelssohn und seine Schule (Hamburg: Hoffmann und Campe, 1840), 37, cited in Michael Meyer, Response to Modernity: A History of the Reform Movement in Judaism (New York: Oxford University Press, 1988), 69. 
can be known "at all times and in all places" through reason or common sense; (b) historical truths about the Jewish nation, including the miraculous exodus from Egypt and the revelation at Mount Sinai, which are known through tradition and recorded in the Torah; and (3) the revealed laws of the Torah. ${ }^{13}$ As the second and third elements include historical doctrines that cannot be known "at all times and in all places," it is evident that Mendelssohn does not identify the doctrines at the core of Judaism solely with universal principles of natural religion. ${ }^{14}$

Second, Mendelssohn does not completely separate universal principles of natural religion from revelation, as he asserts that these universal principles can be communicated through revelation. Thus, Mendelssohn interprets Ecclesiastes as a dialogue teaching the immortality of the soul and he asserts that rational truths about God's existence and providence were revealed to Moses and recorded in the Pentateuch. ${ }^{15}$

Finally, Mendelssohn does not completely separate universal principles of natural religion from ritual law, as he asserts that a primary function of ritual law is to bring the principles of natural religion to life and provide an occasion for contemplating their meaning. As he puts it: "All laws refer to, or are based on, eternal truths of reason, or remind us of them, and rouse us to ponder them. Hence, our rabbis rightly say: the laws and doctrines are related to each other, like body and soul."16

13 Mendelssohn, JubA, 8:191-93; Jerusalem, 126-27.

14 Alexander Altmann notes, however, that in his earlier "Counter-Reflections to Bonnet” (1769) and his 1771 letter to Elkan Herz, Mendelssohn seems to posit a more dualistic concept of Judaism comprising eternal truths and revealed law. See Alexander Altmann, “Moses Mendelssohn's Concept of Judaism Reexamined,” in Von der mittelalterlichen zur modernen Aufklärung: Studien zur jüdischen Geistesgeschichte (Tübingen: Mohr, 1987), 234.

15 Mendelssohn's 1769 Hebrew commentary on Ecclesiastes is found in Mendelssohn, JubA, 14:148207. Edward Breuer and David Sorkin have recently published a translation of a significant portion of this text. See Moses Mendelssohn, Moses Mendelssohn's Hebrew Writings, trans. Edward Breuer, ed. Edward Breuer and David Sorkin (New Haven: Yale University Press, 2018), 123-218. Mendelssohn's most famous discussion of the rational content of revelation in Judaism is in his commentary on Exodus 3:14 on God's revelation of the Tetragrammaton to Moses. Translating the Tetragrammaton as “The Eternal” (Der Ewige), Mendelssohn notes that this concept includes God's eternality, necessary existence, and providential governance. See Mendelssohn, JubA, 16:26-27; Moses Mendelssohn: Writings, 217-18. See also Jerusalem, where Mendelssohn writes: “Although the divine book that we received through Moses is, strictly speaking, meant to be a book of laws containing ordinances, rules of life, and prescriptions, it also includes, as is well known, an inexhaustible treasure of rational truths and religious doctrines that are so intimately connected with the laws that they form but one entity" (emphasis mine). Mendelssohn, JubA, 8:165-66; Jerusalem, 99.

16 See Mendelssohn, JubA, 8:165-66; Jerusalem, 99. For an elaboration of Mendelssohn's argument, see Michah Gottlieb, Faith and Freedom: Moses Mendelssohn's Theological-Political Thought (New York: Oxford University Press, 2011), ch. 2; Gideon Freudenthal, No Religion Without Idolatry: Mendelssohn's Jewish Enlightenment (Notre Dame, IN: University of Notre Dame Press, 2012), ch. 6; and most recently, Elias Sacks, Moses Mendelssohn's Living Script: Philosophy, Practice, History, Judaism (Bloomington: Indiana University Press, 2017), ch. 2. 
Given Mendelssohn's affirmation that the universal principles of natural religion can be revealed and that they are intimately connected to ritual law, in what sense does he deny dogma in Judaism? In the Christian sense, as he asserts that Judaism recognises no divinely commanded irrational doctrines known only through revelation and confirmed by an authoritative religious body the affirmation of which is a necessary condition for salvation. Mendelssohn has three reasons for denying that Judaism possesses dogma in this sense.

First, he claims that Judaism teaches that there are no truths known exclusively through revelation that are necessary for salvation. Were there such truths, they would either contradict God's goodness, by implying that God consigns all those to whom God did not reveal salvational truths to eternal suffering, or they would contradict God's omnipotence, by implying that God lacked the power to provide all people with the tools necessary for salvation. As Mendelssohn memorably put it: "Why must the two Indies wait until it pleases Europeans to send them a few comforters to bring them a message without which they can, according to this opinion, live neither virtuously nor happily?"17

For Mendelssohn, Judaism teaches that salvation depends on the practice of universal morality, which constitutes the true worship of God. ${ }^{18}$ This is reflected in the rabbinic teaching that Gentiles who observe the seven so-called "Noahide laws" merit salvation in the afterlife. ${ }^{19}$ Mendelssohn asserts that the Noahide laws "more or less comprise the essential laws of natural right" and that the talmudic rabbis call those who follow them "virtuous men of other nations" and "children of eternal bliss." ${ }^{20}$ For Mendelssohn, Judaism teaches that the affirmation of universal principles of natural religion is connected to salvation not because affirming these doctrines bestows salvation by itself, but because affirming them provides a crucial mo-

17 See Mendelssohn, JubA, 8:161; Jerusalem, 94.

18 As he put it in his 1770 "Counter-Reflections to Bonnet": "The divine religion into which I was born teaches me that all the peoples of the earth are saved if they live in accordance with the laws of reason, that is, if they practice virtue." Mendelssohn, JubA, 7:90-91; Moses Mendelssohn: Writings, 16.

19 The talmudic doctrine is found in Babylonian Talmud, 'Avodah Zarah, 64b.

20 The rabbinic appellation for Gentiles who follow the Noahide laws is "the pious of the nations of the world" (hasidei ummot ha-'olam). However, Mendelssohn translates the term as "virtuous [tugendhafte] men of other nations," thereby emphasising that moral virtue is the basis for salvation. The seven Noahide laws as enumerated by Mendelssohn involve prohibitions on (1) idolatry; (2) blasphemy; (3) murder; (4) incest; (5) robbery; and (6) eating live animals, as well as (7) the obligation to establish and administer justice. See Mendelssohn's “Open Letter to Lavater” in Mendelssohn, JubA, 7:11; Moses Mendelssohn: Writings, 9. There is a large literature on Mendelssohn's treatment of the Noahide laws. The classic study is Steven Schwarzschild, The Pursuit of the Ideal: Jewish Writings of Steven Schwarzschild, ed. Menachem Kellner (Albany, NY: State University of New York Press, 1990), 29-60. 
tivation for ethical action which merits one salvation. ${ }^{21}$ So, while for Mendelssohn, Judaism teaches that principles of natural religion can be communicated through revelation, it also teaches that revelation is not needed in order to know them. As he puts it: "Judaism boasts of no exclusive revelation of eternal truths that are indispensable to salvation, of no revealed religion in the sense in which that term is usually understood" (emphasis Mendelssohn's). ${ }^{22}$

Second, Mendelssohn claims that according to Judaism, belief in religious dogma cannot be commanded because no beliefs can be commanded. Mendelssohn asserts that human beings have two distinct capacities: intellect, which judges truth, and will, which intends actions. Will can be manipulated through force, threats, and bribes, but intellect only affirms belief on the basis of rational considerations. For example, by holding a gun to my head a person can force me to say the words "one plus one equals three." But they can never force me to believe it. God therefore cannot command belief in dogma, as "ought" must imply "can." ${ }^{23}$ Mendelssohn finds this teaching reflected in the opening of the Decalogue: "I am the Eternal your God who led you from the land of Egypt” (Exodus 20:2). Mendelssohn makes clear that this statement is "not a commandment of belief," since belief cannot be commanded. As he puts it, "a miraculous voice would not have instilled any concepts [...] since [a person] demands rational proofs" (emphasis Mendelssohn's). ${ }^{24}$

For Mendelssohn, just as the eternal truths at the heart of Judaism, such as God's existence, must be affirmed through reason, so too must the historical truths, such as the miraculous exodus from Egypt and the revelation of the Torah on Mount Sinai. Mendelssohn defends the rationality of these teachings by claiming that they can be rationally affirmed on the basis of eye-witness reports and trust in a subsequent chain of tradition. ${ }^{25}$

21 This is a somewhat complex argument that I will not repeat here. For its elaboration, see Michah Gottlieb, Faith, Reason, Politics: Essays on the History of Jewish Thought (Brighton, MA: Academic Studies Press, 2013), 132-38.

22 Mendelssohn, JubA, 8:164; Jerusalem, 97.

23 See Mendelssohn, JubA, 8:129-30; Jerusalem, 61-62.

24 See Mendelssohn, JubA, 8:164-65; Jerusalem, 97-98; JubA, 16:186; Moses Mendelssohn: Writings, 222 (Commentary on Exodus 20:2). Mendelssohn's approach can be seen in a rendering of Maimonides's Thirteen Principles of Judaism that he composed for students at the first maskilic school, the Jüdische Freischule. Maimonides's principles, outlined in his introduction to the tenth chapter of the Talmudic tractate Sanhedrin, were given creedal formulation in the fifteenth century in the anonymous text Ani Ma'amin. In this text, each of Maimonides's principles was prefaced with the phrase "I believe with perfect faith" (ani ma'amin be-emunah šelemah). However, in Mendelssohn's rendering of these principles, he replaced this formulation with the words "I know as true and certain" (Ich erkenne für wahr und gewiß). Mendelssohn's version of Maimonides's Thirteen Principles can be found in Mayer Kayserling, Moses Mendelssohn: sein Leben und seine Werke (Leipzig: H. Mendelssohn, 1862), 565-68.

25 I will not elaborate on Mendelssohn's argument here, but its elements can be found in his commentary on Maimonides's Treatise on Logic in Mendelssohn, JubA, 14:71-72; Moses Mendelssohn's Hebrew Writings, 84-85; Mendelssohn's introduction to his commentary and translation of the Torah, 
Third, Mendelssohn claims that Judaism has never demanded that its adherents swear allegiance to "articles of faith" (Glaubensartikel), the denial of which made one a heretic. He acknowledges that some medieval Jewish thinkers, most notably Maimonides, attempted to create a list of binding articles of faith and claimed that a Jew who did not affirm his articles was not an "Israelite."26 However, Mendelssohn deems Maimonides's idea to be contrary to "the spirit of true Judaism" (Geiste der ächten Judentums), as evidenced by the fact that his principles were disputed by other medieval Jewish thinkers and the debate never led to sectarian divisions or accusations of heresy. ${ }^{27}$

Unlike Maimonides's principles, the first two elements of Mendelssohn's concept of Judaism are general categories rather than specific teachings. Rather than being a litmus test for whether or not a Jew is included in the community, they represent Mendelssohn's analytical understanding of Judaism. Indeed, one of Mendelssohn's most famous teachings is that Judaism deems excommunication illegitimate. ${ }^{28}$

Mendelssohn's denial that Judaism has dogma served an important interreligious function. Mendelssohn was challenged to convert to Christianity several times. The first challenge came in 1769, when the Swiss pastor Johann Caspar Lavater dedicated a philosophical defence of Christianity to Mendelssohn asking him to either refute the defence or convert. The heart of Mendelssohn's response to Lavater was his assertion that he adhered to Judaism because it was a rational, tolerant religion which held that all who practised universal morality merited salvation, which was why Judaism did not proselytise. ${ }^{29}$ Mendelssohn's not-very-subtle implication was that this was not true of Christianity. ${ }^{30}$ So, for Mendelssohn, Judaism's lack of dogma distinguished it from Christianity. Mendelssohn repeated and elaborated this point fourteen years later in Jerusalem, or on Religious Power and Judaism in response to a second challenge to convert to Christianity, this time from the enlightened Protestant writer August Friedrich Cranz.

There was a clear political subtext to Mendelssohn's denial of dogma in Judaism. While the logic of Enlightenment political theory, with its emphasis on human equality and freedom, naturally entailed that Jews should be granted citizenship, many Christians, including Frederick the Great, the enlightened ruler of Prussia, resisted

Mendelssohn, JubA, 14:211-28; Moses Mendelssohn's Hebrew Writings, 241-70; and his discussion of miracles in Mendelssohn, JubA, 7:324-25; Moses Mendelssohn: Writings 255-56. For a recent attempt to defend Mendelssohn's position, see Sacks, Moses Mendelssohn's Living Script, 122-70.

26 On Maimonides's claim, see Kellner, Must a Jew Believe Anything?, 52-56.

27 See Mendelssohn, JubA, 8:167-68; Jerusalem, 100-101. For the history of the dispute over Maimonides's principles, see the books cited in note 2 .

28 See Mendelssohn's "Preface to Menasseh ben Israel” in Mendelssohn, JubA, 7:16-25; Moses Mendelssohn: Writings, 44-52; JubA, 8:103-42; Jerusalem, 33-75.

29 See note 20 above.

30 Mendelssohn made this claim explicit in an unpublished work that he wrote at the time. See Mendelssohn's “Counter-Reflections to Bonnet” in Mendelssohn, JubA, 7:90-105; Moses Mendelssohn: Writings, 16-28. 
this logic. Part of their argument was that Jews could not be granted citizenship because they adhered to a tyrannical, irrational religion which was at odds with Enlightenment principles. ${ }^{31}$ Mendelssohn's claim that Judaism did not possess dogma must therefore be understood in the context of his plea for Jewish civil rights. For Mendelssohn the Maskil and Aufklärer, Judaism's status as a rational, tolerant religion showed it to be more closely aligned with Enlightenment principles than was Christianity.

\section{The Nineteenth-Century Debate}

While Mendelssohn's discussion of dogma in Judaism was informed by the interreligious need to draw a distinction between Judaism and Christianity and advocate for Jewish civil inclusion, in the nineteenth century, the debate was shaped by intrareligious considerations, most notably the problem of Jewish communal unity.

Until the last third of the eighteenth century, most German Jewish communities were organised into traditional structures called qehillot (sing. qehillah). The authority of the qehillah was recognised by Christian rulers and included the right not only to tax its members and administer communal institutions, but also to enforce Halakhah. With the ascension of enlightened absolutist rulers in the eighteenth century who sought to extend a single, rational state law over all the inhabitants of their countries and sweep away estate-based medieval institutions, the authority of the traditional qehillah waned. In this context, new Jewish congregations began to emerge. $^{32}$

Reforming the traditional synagogue service was a central concern for these new Jewish congregations. Between 1810 and 1818, Reform Temples were opened in Seesen, Berlin, and Hamburg. The first reforms introduced included a weekly sermon in German to replace the semi-annual talmudic discourse in Yiddish, some prayers in German rather than all prayers being in Hebrew, and the playing of organ music during the Sabbath prayers. Gradually, substantial changes were introduced into the lit-

31 The literature on this is vast. For a sample of the eighteenth-century arguments against Jewish civil rights, see Jacob Katz, From Prejudice to Destruction: Anti-Semitism, 1700-1933 (Cambridge, MA: Harvard University Press, 1980), 13-62.

32 On the pre-modern qehillah and its decline, see Jacob Katz, Tradition and Crisis: Jewish Society at the End of the Middle Ages, trans. Bernard Dov Cooperman (Syracuse: Syracuse University Press, 2000), and more recently, Elisheva Carlebach, "La communauté juive et ses institutions au début de l'époque moderne," in Aux Origines du Judaïsme, ed. Julien Darmon and Jean Baumgarten (Paris: Actes Sud, 2012), 358-89. In addition to the government stripping the qehillah of prerogatives, its authority was weakened by internal disputes over Sabbateanism, Hasidism, and Haskalah, as well as tensions between the wealthy and the poor. See Katz, Tradition and Crisis, 181-236; Meyer, Response to Modernity, 10-13; Carlebach, "La communauté,” 365-66, 387-89. 
urgy, most notably eliminating the hope that the Jews would return to Palestine, rebuild the Temple, and restore the sacrificial cult in Jerusalem. ${ }^{33}$

In 1844, Reform rabbis convened the first of several rabbinical assemblies to establish unified standards for Reform Judaism. This assembly, held in Braunschweig, proved contentious. However, a few reforms were agreed upon, the most controversial being the ruling that marriage between a Jew and a Christian was not halakhically prohibited as long as children born into the marriage could also be raised as Jews. ${ }^{34}$

Historians generally understand Orthodox Judaism as a reaction to groups perceived to be tampering with Jewish tradition..$^{35}$ Jeffrey Blutinger notes that in the nineteenth century, the term "Orthodox" came to be used specifically to designate Jews opposed to Reform. ${ }^{36}$ As such, the beginnings of nineteenth-century Orthodoxy are often dated to the 1819 publication of a collection of rabbinic responsa opposing the Hamburg Temple titled Eleh Divrei ha-Brit (These Are the Words of the Covenant). ${ }^{37}$ However, it was opposition to the Reform rabbinical assemblies of the 1840s that galvanised and consolidated Orthodoxy. In response to the Braunschweig Assembly, seventy-seven Orthodox rabbis signed a manifesto denouncing it, and a collection of thirty-seven condemnatory rabbinic responsa was published. ${ }^{38}$

The most important of these responsa was that of Samson Raphael Hirsch, the leading exponent of German Jewish Neo-Orthodoxy at the time. Hirsch harshly criticised Reformers for deviating from Halakhah and expressed concern that the actions of the Reformers were precipitating schism among German Jews. As he put it: "You

33 See Meyer, Response to Modernity, 28-61.

34 Meyer, Response to Modernity, 131-35; David Philipson, The Reform Movement in Judaism (New York: Macmillan, 1907), 211-12; Katz, Divine Law in Human Hands (Jerusalem: Magnes Press), 23435, 373. Other reforms included eliminating recital of the Kol Nidrei prayer annulling vows at the beginning of Yom Kippur and eliminating the practice of meșișah be-feh, which involved the person performing the rite of circumcision sucking the penile blood of the baby being circumcised. For a discussion of this ritual and the controversy surrounding it in the nineteenth century, see Katz, Divine Law in Human Hands, 357-402.

35 See Jacob Katz, “Orthodoxy in Historical Perspective," in Studies in Contemporary Jewry, Volume 2, ed. Peter Medding (Bloomington: Indiana University Press, 1986), 3-4; Michael Silber, “Orthodoxy,” in The Yivo Encyclopedia of Jews in Eastern Europe, ed. Gershon Hundert (New Haven: Yale University Press, 2008), 2:1292-97.

36 Jeffrey Blutinger, “'So-Called Orthodoxy’: The History of an Unwanted Label,” Modern Judaism 27, no. 3 (2007): 320.

37 See W. Gunther Plaut, The Rise of Reform Judaism: A Sourcebook of Its European Origins (New York: World Union for Progressive Judaism, 1963), 34. A partial translation of the text can be found in Paul R. Mendes-Flohr and Jehuda Reinharz, The Jew in the Modern World: A Documentary History, 3rd ed. (New York: Oxford University Press, 2011), 187-89.

38 Signatories continued to be gathered and eventually three hundred Orthodox rabbis signed the protest. See Judith Bleich, "Jacob Ettlinger, His Life and Works: The Emergence of Modern Orthodoxy in Germany” (PhD diss., New York University, 1974), 186-91; Philipson, The Reform Movement, 225-29; Katz, Divine Law in Human Hands, 236-43. 
children of the nation, whose assembly has caused all this [protest] [...]. Do your eyes not see that evil and bitterness will follow the path on which you have begun? Do you not know and understand that if your words bear fruit this time, the house of Israel will be torn into two?" 39

Undeterred by Orthodox opponents like Hirsch, Reformers held a second rabbinical assembly in Frankfurt the following year in 1845. At that assembly, a major controversy erupted over whether Hebrew should remain the language of Jewish prayer. Abraham Geiger, the chief rabbi of Breslau and leading theoretician of Reform Judaism, argued that all Hebrew prayers should be eliminated from the synagogue service, since German was the mother tongue of German Jews and, as he put it, "a German prayer strikes a deeper chord than a Hebrew prayer." 40

Geiger's push to eliminate Hebrew from the liturgy was opposed by the leading moderate Reformer, the chief rabbi of Dresden, Zacharias Frankel. Frankel argued that Hebrew must retain a central place in the Jewish liturgy since it was historically the language of Jewish prayer and Scripture, and he dismissed Geiger's contention that German prayers struck a deeper chord than Hebrew prayers as "purely subjective." ${ }^{41}$ Ultimately, the majority of the assembly sided with Geiger, and an outraged Frankel withdrew from the conference, severed his ties with Reform, and founded a separate denomination he called "Positive-Historical Judaism" that charted a middle path between Orthodoxy and Reform. ${ }^{42}$

It would, however, be a mistake to see nineteenth-century German Jewry as marching inexorably towards fragmentation. A powerful impetus for Jewish communal unity came from the Christian governmental authorities. In 1847, Prussia passed a law making it mandatory to belong to the local Jewish community. Jews were required to pay taxes to their local Jewish community, and these taxes were partially used by the supreme Jewish council or Oberat to fund the community's religious institutions, including the local synagogue. According to the governmental regulations,

39 Samson Raphael Hirsch, Sefer Šemeš Marpe': še'elot u-tešuvot, hiddušei ha-Šas, iggerot u-mikhtavim, ed. Eliyahu Meir Klugman (New York: Mesorah, 1992), 195-96. See Katz, Divine Law in Human Hands, 242-44.

40 Geiger also opposed retaining Hebrew for prayer because he saw it as a marker of Jewish nationhood. See Philipson, The Reform Movement, 239-40. For a partial translation of Geiger's arguments, see Mendes-Flohr and Reinharz, The Jew in the Modern World, 203. On the Frankfurt Assembly more generally, see Meyer, Response to Modernity, 136-38; Philipson, The Reform Movement, 231-72.

41 Frankel also rejected Geiger's contention that reciting prayers in Hebrew prevented Jews from being patriotic Germans. For a partial translation of Frankel's response to Geiger, see MendesFlohr and Reinharz, The Jew in the Modern World, 203-4.

42 On Frankel, see Ismar Schorsch, From Text to Context: The Turn to History in Modern Judaism (Hanover, NH: University Press of New England, 1994), 255-65; Andreas Brämer, Rabbiner Zacharias Frankel: Wissenschaft des Judentums und konservative Reform im 19. Jahrhundert (Hildesheim: Olms, 2000). 
a Jew could only be exempted from paying these taxes by withdrawing from the Jewish community by converting to Christianity. ${ }^{43}$

The Oberat did not have a uniform denominational affiliation. In some communities, it was controlled by Reformers, while in others, the Orthodox controlled it. This created tension, since the local community synagogue generally followed the religious orientation of the majority of the Oberat. In a few communities, Jews belonging to a different denomination from the Oberat, whether Reform or Orthodox, received a special governmental dispensation to form an independent congregation and conduct separate services. However, they still had to be members of the official community and pay taxes to it, and were therefore left with a double tax burden, forced to fund religious institutions of which they did not approve. ${ }^{44}$

\section{S.R. Hirsch's Neo-Orthodoxy: Dogma as the Foundation of Denominational Sectarianism}

In 1869, there was a new development in Karlsruhe, the state capital of Baden. The previous year, the Reform-controlled Oberat had introduced reforms into the community synagogue that included the playing of an organ on the Sabbath. The Karlsruhe Orthodox protested and decided not only to form a separate congregation, but also to refuse to pay their communal taxes. This amounted to seceding from the official Jewish community, and the Oberat promptly sued the Orthodox secessionists. However, Baden had a tradition of progressive liberalism, and the State Supreme Court acquitted the Orthodox Jews, accepting their argument that they had a right to secede for reasons of liberty of conscience. In response, the Oberat issued a harsh public condemnation of the Orthodox secessionists. At the heart of the Oberat's attack was a claim about the theological tenets of Judaism. ${ }^{45}$

43 See Salo Baron, "Freedom and Constraint in the Jewish Community: An Historic Episode," in Essays and Studies in Memory of Linda R. Miller, ed. Israel Davidson (New York: Jewish Theological Seminary, 1938), 11-12; Robert Liberles, Religious Conflict in Social Context: The Resurgence of Orthodox Judaism in Frankfurt Am Main, 1838-1877 (Westport, CT: Greenwood Press, 1985), 167-69; Jacob Katz, A House Divided: Orthodoxy and Schism in Nineteenth-Century Central European Jewry, trans. Ziporah Brody (Hanover, NH: Brandeis University Press, 1998), 9.

44 Reformers formed a separate congregation in Berlin from 1847 to 1858 and in Hamburg from 1819 until 1865, when the official Jewish community was dissolved after emancipation was granted. The Orthodox formed separate congregations in Frankfurt, Mainz, Cologne, Darmstadt, Karlsruhe, and Wiesbaden. A different type of arrangement existed in Breslau from 1846 to 1856, where Orthodoxy and Reform had equal status and a person could choose which congregation to join. Robert Liberles notes, however, that in 1858, members of the Reform congregation in Berlin were exempted from paying taxes to the official Jewish community, despite remaining members of it. Given that the Hamburg official community was dissolved in 1865 , by that year, no Reformers in German lands suffered from double taxation, only Orthodox Jews did. See Liberles, Religious Conflict, 172-73.

45 See Katz, A House Divided, 237-38. 
The Oberat charged the Orthodox with "religious indifference" and with lacking a proper "sense of community" (Gemeinsinn), since for generations, Jews had regarded membership in the local Jewish community as an inviolable religious obligation. ${ }^{46}$ The Oberat understood that the Orthodox saw secession as a matter of religious principle. However, it rejected this argument, claiming that the dispute between Orthodoxy and Reform amounted to "a minor difference of opinion over certain provisions in religious services which has not the least bearing on principles of religion [Religionsgrundsatz]." ${ }^{47}$ According to the Oberat, Orthodox and Reform Jews affirmed the same basic religious dogmas. For the Orthodox to tear the community apart over minor disagreements concerning the synagogue service was petty and unconscionable.

In response, the Orthodox faction in Karlsruhe appealed to Samson Raphael Hirsch, the leader of a separatist Orthodox congregation in Frankfurt, for support. In the late 1860s, as Orthodox secession was debated in Hungary, Hirsch nursed the hope that his own Orthodox congregation in Frankfurt would be able to secede from the official Reform-controlled community there. ${ }^{48}$ As such, he was eager to support the Orthodox faction in Karlsruhe. In April 1870, he published a blistering reply to the Karlsruhe Oberat titled "Die Trennungsfrage in Karlsruhe" ("The Secession Question in Karlsruhe"). ${ }^{49}$

For Hirsch, the dispute between Orthodoxy and Reform was no matter of minor differences over the synagogue service, but rather a "symptom" of a much deeper disagreement between them. ${ }^{50}$ Hirsch had long battled to affirm the principle of the timeless, unchanging nature of the Torah whose laws were binding on all Jews. ${ }^{51}$ According to Hirsch, the Orthodox followed the traditional Jewish view that "the first and most fundamental principle of Judaism" was the acceptance that all Jewish life-including not only the synagogue service, but also all domestic and public life-should be governed by Halakhah as found in the Bible, Talmud, and later rabbinic rulings and customs (minhagim) whose final authoritative codification was in the sixteenth-century Šulhan 'Arukh. ${ }^{52}$ By contrast, Reformers regarded Juda-

46 Samson Raphael Hirsch quotes the Oberat's argument. See Samson Raphael Hirsch, Gesammelte Schriften, ed. Mendel Hirsch, 6 vols. (Frankfurt am Main: J. Kauffmann, 1902-12), 5:532 (henceforth: $G S)$.

47 Hirsch, GS, 5:532.

48 Katz notes that in the 1850s, Hirsch sought exemption from paying taxes to the community that would be used to support Reform institutions, but did not yet conceive of full Orthodox secession. See Katz, A House Divided, 27. On the effect of events in Hungary on Hirsch, see Katz, A House Divided, 108-10, 237.

49 The text is reprinted in Hirsch, GS, 5:532-42.

50 Hirsch, GS, 5:535. Hirsch used the term "Neologie" to refer to Reformers.

51 For a discussion of Hirsch's arguments, see Michah Gottlieb, "Oral Letter and Written Trace: Samson Raphael Hirsch on the Bible and Talmud," Jewish Quarterly Review 106, no. 3 (2016): 316-51. 52 Hirsch, GS, 5:534. In his 1836 Neunzehn Briefe über Judentum, Hirsch wrote that while Maimonides's Thirteen Principles "perhaps" (vielleicht) serve as a basis for Judaism, they do not constitute the 
ism as comprising a few simple theological beliefs and the universal moral law, while Halakhah was largely seen as antiquated and hence no longer obligatory. ${ }^{53}$ As such, Hirsch contended that the dispute between Orthodoxy and Reform was no minor spat, but rather reflected differences "far greater [...] than the opposition between Catholic and Protestant, Lutheran and Reformed, or any other different Christian ecclesiastical confessions." 54

For Hirsch, it was Reformers, not the Orthodox, who had precipitated religious schism by changing Judaism's traditional religious principles. While the Oberat claimed that it was fighting to preserve historical Judaism, since pre-modern Jews regarded membership in the local qehillah as a religious obligation, Hirsch argued that this was a distortion of history because the basis of membership in the Jewish community had changed. Hirsch asserted that pre-modern Jews freely consented to be members of the qehillah because the community defined itself by the dogma that obedience to divinely revealed Halakhah was mandatory. ${ }^{55}$ By contrast, the Oberat defined communal membership as the payment of taxes, enforced by non-Jewish governmental authorities. For Hirsch, this artificial, oppressive basis of Jewish communal unity had nothing to do with historical Judaism, and so the Orthodox were entirely justified in seceding. ${ }^{56}$ As he put it, "it is not a common tax box, but a com-

totality of it. See Samson Raphael Hirsch, Neunzehn Briefe, 2nd ed. (Frankfurt: J. Kauffmann, 1889), brief 17, 94. The English translation edited by Joseph Elias omits Hirsch's "vielleicht." See Samson Raphael Hirsch, The Nineteen Letters about Judaism, trans. Karin Paritzky, ed. Joseph Elias (New York: Feldheim, 1995), letter 17, 244. In his 1854 essay "Religion Allied to Progress," Hirsch was more forceful in rejecting Maimonides's Thirteen Principles, claiming that there could be no principles of Judaism since every commandment is fundamental. As he put it: "The rabbinical authorities opposed the proclamation of Jewish articles of faith [Glaubensartikeln] not because Judaism has no basic tenets, but because they regarded every aspect of Judaism as basic. Judaism, they held, knows neither thirteen articles of faith, nor three. In Judaism, every commandment and every prohibition constitutes a fundamental religious principle and the denial of even one of the 613 commandments and prohibitions thereby places oneself outside Judaism." Hirsch, GS, 3:492; Hirsch, The Collected Writings, ed. Marc Breuer, Jacob Breuer, Meta Bechhofer, and Elliot Bondi (New York: Feldheim, 1984-2012), 6:112. Mendelssohn made a similar point in Jerusalem which he attributed to "Luria and the latter-day Kabbalists." Zev Harvey notes that Mendelssohn was actually referring to the view of the sixteenth-century rabbi David ibn Zimra (Radbaz), who was Isaac Luria's teacher. See Warren Zev Harvey, "Hasdai Crescas and Moses Mendelssohn on Beliefs and Commandments," in Moses Mendelssohn: Enlightenment, Religion, Politics, Nationalism, ed. Michah Gottlieb and Charles H. Manekin (Bethesda: University Press of Maryland, 2015), 85-86. Mendelssohn made his sympathy for this position evident, writing that "laws cannot be abridged. In them everything is fundamental, and in this regard we may rightly say: to us, all words of Scripture, all of God's commandments are fundamental." See Mendelssohn, JubA, 8:167-68; Jerusalem, 100-101. The originator of this view was Maimonides's fifteenth-century critic Isaac Abravanel in his 1494 work Roš Amanah. See Kellner, Dogma in Medieval Jewish Thought, 179-95.

53 Hirsch, GS, 5:535.

54 Hirsch, GS, 5:539.

55 See Katz, A House Divided, 238-39.

56 Hirsch, GS, 5:536-38. 
mon creed [das gemeinsame religiöse Bekenntnis] that makes a community a community" (emphasis mine). ${ }^{57}$

The dogma that Hirsch affirmed as central to Judaism was very similar to Mendelssohn's third element of Judaism, and Hirsch followed Mendelssohn in rejecting dogma in the sense of a commandment to believe in revealed doctrines, instead asserting that the revealed law was to be accepted on the basis of rational considerations. ${ }^{58}$ Hirsch's sense of affinity with Mendelssohn can be seen in an article attacking the Reformers that he published sixteen years before the events in Karlsruhe. While the Reformers lionised Mendelssohn as their pioneer, Hirsch asserted that "the thesis of all of Mendelssohn's writings is that Judaism is essentially a law." Hirsch then asked the Reformers: "Do you seriously believe that if [...] Mendelssohn were to come into your midst today he would accept you as one of his own?"59

For Hirsch, the obligation to fulfill all the laws of the revealed Torah was the basic dogma of Judaism. Accepting it constituted the basis for membership in the Jewish community and served as a test of Orthodoxy. If the leadership of the official, government-recognised Jewish community broke with this traditional Jewish dogma, then those who remained loyal to it had no choice but to form a separate Jewish community.

\section{Manuel Joël's Positive-Historical Judaism: Dogma as a Basis of Pan-Communal Unity}

As secession was being debated in Karlsruhe and Hungary, many German Jewish leaders were growing increasingly worried that Orthodox separatism would spread, with disastrous results. ${ }^{60}$ They worried that without a unified tax base, many smaller Jewish communities would become financially insolvent and disintegrate. Among those most concerned about this was Manuel Joël, the chief rabbi of Breslau and a close associate of Zacharias Frankel who identified with his "Positive-Historical" banner. The idea of Jewish communal unity was central to Frankel and to PositiveHistorical Judaism, and Joël's position must be understood in light of Frankel's.

At the Frankfurt Conference, Frankel, who called himself a "moderate [gemäßigte] Reformer," presented his view of how reforms should be introduced into Judaism. ${ }^{61}$ For Frankel, only Judaism's laws were subject to evolution, not its beliefs, so any reform of Judaism had to apply only to Halakhah. He noted that in undertaking

57 Hirsch, GS, 5:539.

58 See Hirsch, Neunzehn Briefe, brief 15, 79; Nineteen Letters, letter 15, 200.

59 Hirsch, GS, 3:494, 504; Collected Writings 6:114, 124.

60 On secession in Hungary, see Katz, A House Divided, 31-236.

61 On this label, see Zacharias Frankel, "Über Reformen im Judenthume," Zeitschrift für die religiösen Interessen des Judenthums 1, no. 1 (1844): 27. 
any reforms, concern had to be directed to the needs of the people as a whole, not to the needs of isolated individuals. A primary concern had to be to "prevent any split [Zerspaltung]" in Judaism and to avoid creating new factions. Instead, one should seek to reconcile existing groups. ${ }^{62}$ Joël's 1869 pamphlet "Zur Orientirung in der Cultusfrage” (“On the Question of Religious Worship”) clearly reflected his sympathy with Frankel's commitment to Jewish communal unity and his sense that Jewish beliefs were not subject to reform. At the heart of Joël's argument was his contention that dogma was central to Judaism. ${ }^{63}$

Like the Karlsruhe Oberat, Joël argued that the Orthodox had no reason to secede from the official Jewish community since Orthodoxy and Reform accepted the same basic religious principles. However, while the Oberat had left these common principles vague, Joël sought to give a more precise definition of what he called the "dogma" of Judaism. He noted that religious dogmas were not specific to Judaism, since "every positive religion has specific dogmas [gewisse Dogmen] which it regards as fixed and the denial of which causes one to cease being a member [of the religion]." 64 Like Mendelssohn, Joël rejected the binding authority of Maimonides's Thirteen Principles of Judaism, observing that important later Jewish thinkers had disputed them. ${ }^{65}$ But rather than seeing all of Jewish law as of binding authority or describing general categories of Jewish beliefs as had Mendelssohn, Joël identified two specific theological "beliefs" (Glaubensvorstellungen) as Jewish dogma. ${ }^{66}$

We have seen that the question of how to conduct the synagogue service was central to the emergence of German Jewish denominationalism. Joël's approach to dogma clearly reflected his concern with debates over the synagogue, as indicated by the title of his essay ("On the Question of Religious Worship"-emphasis mine). For this reason, rather than presenting dogmas as conceptual principles upon which Judaism was constructed, Joël interpreted dogmas as creedal declarations expressed in the synagogue liturgy, ${ }^{67}$ and sought out the theological principles that formed the foundation of this liturgy.

Joël concluded that Judaism rested on two dogmas: a monotheistic representation of God and the existence of prophecy and revelation. ${ }^{68} \mathrm{He}$ contended that both the Orthodox and the Reform liturgy affirmed these dogmas and that they therefore belonged to the same confession. Disputes between the Orthodox and Reformers over whether the liturgy should express hope for a personal messiah who would re-

62 See Protokolle und Aktenstücke der zweiten Rabbiner-Versammlung (Frankfurt: E. Ullmann, 1845), 20.

63 Manuel Joël, Zur Orientirung in der Cultusfrage (Breslau: Schletter'sche Buchhandlung, 1869). 64 Joël, 10.

65 Joël.

66 Joël, 11. Joël notes the importance of history in Judaism, but does not consider belief in specific historical narratives to be Jewish dogma. See Joël, 7-8.

67 On creed vs. dogma, see above, note 1.

68 Joël, 11-12. 
store the Jews to Palestine and rebuild the Temple in Jerusalem or over the question whether or not sacrifices had atoning power were not disputes over fundamental Jewish dogmas. Rather, they were minor disagreements, since these ideas had what Joël called a "contested history" within Judaism. ${ }^{69}$ As such, arguments over these ideas did not provide legitimate grounds for tearing the community apart.

Joël acknowledged that Reformers and the Orthodox had radically different interpretations of the two dogmas of Judaism he had enumerated. This was most evident with the dogma of prophecy/revelation which Orthodoxy understood to involve God's revelation of the Written and Oral Torah to Moses, an idea that Reformers largely rejected. However, for Joël, this was not a problem, for while monotheism and prophecy/revelation were Jewish dogmas, they were never given a "final, fixed form," and thus there was much latitude in how to interpret them. Joël claimed that this vagueness was "salutary for Judaism" as it allowed different points of view to be included in the tradition. ${ }^{70}$ Yet he made clear that there were limits to how these dogmas could be interpreted. The Bible and what Joël called "later Jewish religious texts" constituted a definite boundary to Judaism. As such, he asserted that "ideas that clearly and unquestionably [fraglos] contradict the letter and spirit of Jewish religious texts" lay outside Judaism. ${ }^{71}$

Like Mendelssohn, Joël rejected dogmas in the sense of irrational revealed truths commanded by God whose affirmation was a precondition for salvation. However, unlike Mendelssohn he focused his account of the principles of Judaism on particular-albeit vaguely defined-creedal declarations of belief as expressed in the liturgy, which Joël was happy to call “dogma.” The reason for this shift was that Joël's primary concern was to provide a basis for Jewish communal unity in the face of the threat of Orthodox secession, where the synagogue service was a central point of contention.

\section{Abraham Geiger's Reform: Judenheit as Basis of Communal Unity}

Shortly after the appearance of Joël's pamphlet, Abraham Geiger published a long, devastating attack on it titled "Etwas über Glauben und Beten: $\mathrm{Zu}$ Schutz und Trutz” (“On Belief and Prayer: Protection and Defence”). ${ }^{72}$ Twelve years earlier, Gei-

69 Joël, 11.

70 Joël, 10.

71 Joël, 10. Joël uses the term Schriftwidriges, but in light of the fact that he considers not only the Bible, but also later Jewish religious texts as constituting a clear boundary of Judaism, I think he means Jewish sacred texts more generally, especially rabbinic texts.

72 Abraham Geiger, "Etwas über Glauben und Beten: Zu Schutz und Trutz," Jüdische Zeitschrift für Wissenschaft und Leben 7 (1869): 1-59. Geiger's review clearly had a personal dimension. At the time, he and Joël were competing for a rabbinical position in Berlin, which Geiger was ultimately offered. 
ger had published his groundbreaking Urschrift und Übersetzungen der Bibel in ihrer Abhängigkeit von der innern Entwicklung des Judenthums (Original Text and Translation of the Bible in Its Dependence on the Inner Development of Judaism). The key argument of the Urschrift was that different schools of Judaism had rewritten the Bible to fit their needs. ${ }^{73}$ This reflected a radical expansion of Geiger's understanding of the evolution of Judaism that he had expressed two decades earlier in a critique of Hirsch's Neunzehn Briefe. There, Geiger had emphasised the development of Judaism by contending that the talmudic rabbis used fanciful exegesis to modify the biblical letter to make it speak "for their time."74

Geiger began "Etwas über Glauben und Beten” by accusing Joël of incoherence. How could Joël claim that Judaism had dogma without fixed forms, but then claim that this lack of fixed forms had been beneficial for Judaism? As Geiger put it, "dogma without fixed forms, concepts without conceptual determination, signify nothing." "75 However, Geiger's deeper criticism was animated by his critical understanding of history. He noted that Joël sought to set boundaries on the interpretation of Jewish dogma by asserting that interpretations which "clearly and unquestionably" violated the spirit or the letter of the Bible must be rejected. But Geiger observed that what clearly violated the spirit and letter of the Bible for one person might not for another. Who got to decide which interpretations of dogma were legitimate and which were not? ${ }^{76}$

Geiger noted that Joël had claimed that not just the Bible, but also "later Jewish religious texts" constituted a "definite boundary" of legitimate Jewish ideas. But Joël did not specify which later Jewish texts he was referring to. Geiger observed that the Orthodox could easily claim that these texts included not just the Talmud, but even the Šulhan 'Arukh, concluding that any religious ruling that contravened the Šulhan 'Arukh lay outside Judaism. ${ }^{77}$

See Max Wiener's introduction in Abraham Geiger, Abraham Geiger and Liberal Judaism: The Challenge of the Nineteenth Century, rev. ed., trans. Ernst J. Schlochauer, ed. Max Wiener (Cincinnati: Hebrew Union College Press, 1981), 65-66.

73 For discussion of Geiger's Urschrift, see Susannah Heschel, Abraham Geiger and the Jewish Jesus (Chicago: University of Chicago Press, 1998), 76-83, 121-22; Ken Koltun-Fromm, Abraham Geiger's Liberal Judaism: Personal Meaning and Religious Authority (Bloomington: Indiana University Press, 2006), 44-50; Nahum M. Sarna, Studies in Biblical Interpretation (Philadephia: Jewish Publication Society, 2000), 161-72.

74 See Abraham Geiger, "Recension der Briefe über Judenthum (3)," Wissenschaftliche Zeitschrift für jüdische Theologie 3, no. 1 (1837): 90. For discussion of Geiger’s complex early attitudes towards rabbinic exegesis, see Jay M. Harris, How Do We Know This? Midrash and the Fragmentation of Modern Judaism (Albany, NY: State University of New York Press, 1995), 157-65; Heschel, Abraham Geiger and the Jewish Jesus, 25-26; Koltun-Fromm, Abraham Geiger's Liberal Judaism, 40-63.

75 Geiger, "Etwas über Glauben und Beten," 7.

76 Geiger, 14.

77 Geiger. 
Geiger then turned to Joël's specific account of Jewish dogma. He noted that while Joël claimed that Judaism had universally acknowledged dogmas that received their imprimatur in the liturgy, he enumerated only two such dogmas: monotheism and prophecy/revelation. However, Geiger observed that the traditional Jewish liturgy included a plethora of other ideas, including the resurrection of the dead, belief in angels, and the existence of miracles. "Why did Joël not include these as dogmas of Judaism?" he asked. ${ }^{78}$ Geiger further argued that while Joël asserted that the expectation of a personal messiah and the atoning power of sacrifices had a disputed history, this did not reflect the historical record. Until the modern period, almost no Jews seriously doubted the coming of a messiah who would lead the Jews to Palestine, rebuild the Temple, and restore the sacrificial cult and these ideas were clearly affirmed in the traditional Jewish liturgy. ${ }^{79}$

Geiger then criticised Joël's claim that the dogmas of monotheism and prophecy/ revelation had never been disputed. Maimonides claimed that monotheism required the belief that God is incorporeal and that a person who believed that God has a body was no longer a Jew. But his older contemporary Rabbi Abraham ibn Daud responded that there were men better than Maimonides who believed that God had a body and Jewish corporealists were never excluded from the synagogue. Moreover, while Joël made monotheism a principle, presumably to exclude the Christian belief in the Trinity and the Incarnation, Kabbalah posited a God composed of ten persons. ${ }^{80}$

Geiger concluded that Judaism has no dogma, a position he ascribed to Mendelssohn. But interpreting Mendelssohn as contending that revealed ritual law is the defining feature of Judaism, Geiger called Mendelssohn's approach an "unhappy thought" that "turned [Judaism] into a lifeless skeleton," since for Geiger, the ritual law had lost its relevance. ${ }^{81}$

In rejecting dogma, Geiger did not deny the importance of doctrines in Judaism. Indeed, he regarded doctrines as Judaism's defining characteristic. What Geiger was contesting was the notion that any specific, fixed ideas were constitutive of Judaism. Instead, he adopted a teleological view of Judaism, seeing its religious ideas as continually developing and undergoing purification. For Geiger, Judaism's “spiritual power" (Geistesmacht) derived from its capacity to tolerate and nourish a diversity of ideas, even contradictory ones, and to continually evolve new, more potent concepts. $^{82}$

But, Geiger asked, how did one determine which ideas were Jewish and which were not? The standard could not be conformity to some arbitrary definition of "Judaism" (Judentum). Rather, what made an idea Jewish was that the person introduc-

78 Geiger, 7.

79 Geiger.

80 Geiger, 9.

81 Geiger, 7.

82 Geiger, 7-8. 
ing it "feels connected to Judenheit and [...] knows himself to be in accordance with the spirit [Geist] prevailing in Judenheit [...] even if he departs from conventional approaches in essential questions." 83

83 Geiger, 9. Geiger's position in this text seems to contradict views he presents in other texts. In 1858, he published a fictional correspondence titled Über den Austritt aus dem Judenthume: ein aufgefundener Briefwechsel (On Secession from Judaism: A Newly Discovered Correspondence). This correspondence was between a Jewish merchant who had recently converted to Christianity and a Reform rabbi who questions the decision. The rabbi asks the convert how he could abandon Judaism with its "basic principle" (Grundgedanke) of belief in a "unique, holy, living God" in favour of Christianity with its belief in irrational doctrines such as the Trinity, the Incarnation, Original Sin, and Vicarious Atonement through faith in Jesus. See Abraham Geiger, Abraham Geiger's nachgelassene Schriften, ed. Ludwig Geiger (Berlin: Louis Gerschel Verlagsbuchhandlung, 1875), 1:234-35. Shortly after Geiger's essay appeared, a Jewish convert to Christianity named Martin Maass attacked it. Noting that the rabbi in Geiger's dialogue did not consider Jewish ceremonial law to be binding, Maass contended that absent ceremonial law, Geiger's Reform Judaism was nothing but "abstract Deism" or "vestigial Voltairianism" (zurückgebliebenen Voltairianismus) that lacked anything distinctly Jewish. Geiger responded to Maass with a 35-page "open letter" in which he asserted that "the actual kernel of Judaism is pure faith in God [reine Gottesglaube] and whoever firmly cleaves to this basic kernel is a Jew." See Abraham Geiger, Über den Austritt aus dem Judenthume: Offenes Sendschreiben an Herrn. M. Maaß (On Secession from Judaism: Open Letter to Mr. M. Maass) (Breslau: J. U. Kern, 1858), 10. Geiger then detailed a series of doctrines that he deemed foundational in Judaism, including belief in a unique, holy, living God who is the creator and preserver of the universe; God as the source of laws governing nature and human life; God being revealed in all stirrings of human good; God as the source of the spiritual development of humanity throughout all of history; that the divine spirit exists in all human strivings in art and science; that humans are the only beings created in the image of God; that human beings have two divine gifts, free will and reason, by which they strive for perfection; that human beings alone can commune with God; that God's fundamental commandment is to love one's neighbour as oneself; that the messianic task is to perfect humanity so that all humanity will revere the unique God in peace and love, etc. Geiger called these doctrines the "faith content [Glaubensbehalt] of Judaism" and made it clear that these beliefs were never systematised. Nonetheless, his emphasis on certain doctrines being essential in Judaism seems to differ from his more openended, amorphous account of Jewish doctrines laid out in "Etwas über Glauben und Beten." Similarly, in an 1846 work on Jewish religious instruction, Geiger presents three principles of Judaism, namely belief in: (1) a unique holy God; (2) human beings having superior dignity on account of their being created in God's image; (3) human beings being called to work towards the universal brotherhood of mankind united in love. See Geiger, "Abhandlung aus den Programmen der jüdischen Religionsunterrichtsanstalt," in Geiger, Abraham Geiger's nachgelassene Schriften, 1:323, cited in Brämer, "Abraham Geiger- skeptischer Pionier einer Glaubenslehre des Reformjudentums?," in Yearbook of the Maimonides Centre for Advanced Studies 2018, ed. Bill Rebiger (Berlin: De Gruyter, 2018), 228-29. The differences between "Etwas über Glauben und Beten," and these other texts may be due to Geiger's different aims in each text which leads him to employ different methodological approaches. In Über den Austritt aus dem Judenthume: Offenes Sendschreiben, Geiger seeks to give Judaism positive content in order to distinguish it from Deism and in "Abhandlungen aus den Programmen der jüdischen Religionsunterrichtsanstalt" he seeks to specify principles of Judaism for the instruction of Jewish youth. As such he presents his own normative, theological conception of Judaism. By contrast, in "Etwas über Glauben und Beten" he uses an academic, historical approach to refute Joël's assertion that Judaism can be defined by specific dogmas. 
Geiger's term Judenheit is parallel to the term Christenheit, which is generally translated as "Christendom." Just as Christenheit signifies all the members of the Christian religion, so Geiger's Judenheit signifies all the members of the Jewish religion. For Geiger, one could never be certain from the outset what constituted an authentic Jewish idea, and this was subject to change. For example, he observed that at one time, Kabbalah had enjoyed wide acceptance within Judaism, but that at present, its fantastic excesses had "been fought and overcome." ${ }^{84}$ Instead, Geiger asserted that history was decisive and that Jews should "trust Judaism's power to spiritually weed out the foreign and smooth out perversions." The greatest danger was trying to draw clear boundaries to Judaism, as this would end up suffocating it. Granting Jewish thinkers the full freedom to develop their ideas would be what would preserve Judaism's life and vitality for the future. For Geiger, identification with Jewish religion in general rather than affirming specific ideas or practices constituted the basis of Jewish communal unity.

Geiger concluded by addressing the problem of schism. He acknowledged that his approach would not deter Orthodox secessionists, since they defined Judaism by adherence to all the laws in the Šulhan 'Arukh and considered Jews who denied this to be outside of Judaism. However, he asserted that Joël's attempt to avoid schism by arbitrarily selecting vaguely defined dogmas which he declared to be binding on all Jews was no solution, since the Orthodox would simply reject this. ${ }^{85}$ Geiger made clear that while he was not in favour of schism, he did not fear it. ${ }^{86}$ Protestantism had brought schism to Christianity, but in doing so, it had freed itself from Catholicism's stifling hierarchy and laid the ground for spiritual progress and Bildung. What was most important for the future of Judaism was freedom. As he put it: "In religious life, freedom certainly precedes unity [geht sicher die Freiheit vor der Einheit]!"87

84 Geiger, "Etwas über Glauben und Beten," 9.

85 Geiger, 15-16. For his part, Joël was likely not concerned with convincing Orthodox Jews of his views, but rather with convincing the governmental authorities so that they would deny Orthodox Jews the right to secede from the official Jewish community.

86 Geiger, 22, 25. Geiger's attitude towards religious schism was highly ambivalent. Liberles notes that in 1831, when Reform was a small minority, he had favoured Reformers forming separate communities. Between 1839 and 1841, Geiger vacillated on the question. By 1846, as Reform had established a dominant position among German Jews, he opposed secession. However, as we can see from his 1869 essay, Geiger did not oppose secession at all costs. See Liberles, Religious Conflict, 165-67. See also Michael Meyer, "Universalism and Jewish Unity in the Thought of Abraham Geiger," in The Role of Religion in Modern Jewish History, ed. Jacob Katz (Cambridge, MA: Association for Jewish Studies, 1975), 91-107.

87 Geiger, “Etwas über Glauben und Beten,” 25-26. 


\section{Conclusion}

Writing in the eighteenth century, Mendelssohn addressed the question of dogma in Judaism from an interreligious perspective as a means of distinguishing Judaism from Christianity. For Mendelssohn, Judaism's lack of dogma involved its rejecting the idea that affirming irrational revealed doctrines commanded by God and confirmed by an authoritative religious body was a precondition for salvation. According to Mendelssohn, Judaism taught that all human beings could attain salvation by practising natural religion which could be known universally through reason or common sense. Mendelssohn also denied that Judaism was defined by an authoritative list of articles of faith which, if denied, made one a heretic. Mendelssohn's own account of the three components of Judaism referred, for the most part, to general classes of principles and expressed his analytical understanding of Judaism rather than being a normative means of excluding heretics. In defining Judaism as he did, Mendelssohn sought to show that Judaism was more consistent with the enlightened principles of rationality and tolerance than was Christianity and hence that Jews were eligible for civil inclusion. His approach reflected his maskilic view that Judaism was an enlightened religion of reason (Vernunftreligion). ${ }^{88}$

In the nineteenth century, the debate over dogma in Judaism came to be shaped by intrareligious concerns; namely, the problem of Jewish communal unity. Several writers, including the members of the Reform-controlled Oberat in Karlsruhe, the Positive-Historical rabbi Manuel Joël, and the Neo-Orthodox rabbi Samson Raphael Hirsch all affirmed that Judaism had dogma in the sense of a set of fixed doctrines and/or practices. This claim served as a justification either for pan-Jewish communal unity or for Orthodox Jewish sectarianism. Joël's view reflected the Positive-Historical commitment to Jewish communal unity, while Hirsch's view reflected his Orthodox commitment to the authority of the timeless, unchanging, revealed laws of the Torah.

Geiger's approach to the question of dogma in Judaism was the most radical. He rejected dogma not only in the Christian sense, but also in the sense in which Joël and Hirsch had defined it; namely, the idea that specific doctrines were constitutive of Judaism. While not denying the centrality of doctrines in Judaism, Geiger saw the basis of Jewish communal unity in what he called Judenheit, which was grounded in a subjective sense of belonging to a religious community rather than espousing certain beliefs or engaging in specific practices. Geiger's emphasis on the centrality of intellectual freedom lead him to a much weaker commitment to Jewish communal unity than that espoused either by the Reform-controlled Oberat in Karlsruhe or

88 Mendelssohn acknowledged that some Christians, such as Unitarians, adhered to a religion which, like Judaism, was rational, and he declared: "We must almost regard Unitarians as fellow believers." For Mendelssohn, the difference between Orthodox Christian teachings and Unitarianism was much greater than the difference between Judaism and Unitarianism. See Mendelssohn, JubA, 7:102-6; Moses Mendelssohn: Writings, 26-30. 
by Joël. This nineteenth-century debate over whether or not Judaism has dogma is thus a pivotal debate intimately tied to the problem of Jewish communal unity.

A fascinating sequel to the nineteenth-century debate occurred in the first third of the twentieth century and involved many of the leading German Jewish scholars and rabbis of the time, including Leo Baeck, Julius Guttmann, Max Wiener, and Alexander Altmann. Here the question of dogma in Judaism again returned to being an interreligious one. Exploring this debate will have to await another occasion. ${ }^{89}$

\section{Bibliography}

Altmann, Alexander. “Moses Mendelssohn's Concept of Judaism Reexamined.” In Von der mittelalterlichen zur modernen Aufklärung: Studien zur jüdischen Geistesgeschichte, 234-48. Tübingen: Mohr, 1987.

Baeck, Leo. "Does Traditional Judaism Possess Dogmas?” In Studies in Jewish Thought: An Anthology of German Jewish Scholarship, edited by Alfred Jospe, 41-53. Detroit: Wayne State University Press, 1981.

Baron, Salo. "Freedom and Constraint in the Jewish Community: An Historic Episode." In Essays and Studies in Memory of Linda R. Miller, edited by Israel Davidson, 9-24. New York: Jewish Theological Seminary, 1938.

Bleich, Judith. "Jacob Ettlinger, His Life and Works: The Emergence of Modern Orthodoxy in Germany.” PhD diss., New York University, 1974.

Blutinger, Jeffrey. “'So-Called Orthodoxy': The History of an Unwanted Label.” Modern Judaism 27, no. 3 (2007): 310-28.

Brämer, Andreas. "Abraham Geiger- skeptischer Pionier einer Glaubenslehre des Reformjudentums?" in Yearbook of the Maimonides Centre for Advanced Studies 2018, Edited by Bill Rebiger, 207-30. Berlin: De Gruyter, 2018.

Brämer, Andreas. Rabbiner Zacharias Frankel: Wissenschaft des Judentums und konservative Reform im 19. Jahrhundert. Hildesheim: Olms, 2000.

Carlebach, Elisheva. "La communauté juive et ses institutions au début de l'époque moderne." In Aux Origines du Judaïsme, edited by Julien Darmon and Jean Baumgarten, 358-89. Paris: Actes Sud, 2012.

Darlap, Adolf, and Karl Rahner. "Dogma." In Encyclopedia of Religion, 2nd ed., edited by Lindsay Jones, 4:2387-90. Detroit: Macmillan, 2004.

Frankel, Zacharias. “Über Reformen im Judenthume.” Zeitschrift für die religiösen Interessen des Judenthums 1, no. 1 (1844): 3-27.

Freudenthal, Gideon. No Religion without Idolatry: Mendelssohn's Jewish Enlightenment. Notre Dame, IN: University of Notre Dame Press, 2012.

Friedländer, David. Der Prediger. Berlin: Friedrich Maurer, 1788.

Geiger, Abraham. Abraham Geiger and Liberal Judaism: The Challenge of the Nineteenth Century. Rev. ed. Translated by Ernst J. Schlochauer. Edited by Max Wiener. Cincinnati: Hebrew Union College Press, 1981.

89 On this debate, see von der Krone, "Jüdische Wissenschaft und modernes Judentum: eine Dogmendebatte," in Die "Wissenschaft des Judentums": Eine Bestandsaufnahme, ed. Thomas Meyer and Andreas Kilcher (Paderborn: Wilhelm Fink Verlag, 2015), 125-38. 
Geiger, Abraham. Abraham Geiger's nachgelassene Schriften. Edited by Ludwig Geiger. 5 vols. Berlin: Louis Gerschel Verlagsbuchhandlung, 1875.

Geiger, Abraham. "Etwas über Glauben und Beten: Zu Schutz und Trutz." Jüdische Zeitschrift für Wissenschaft und Leben 7 (1869): 1-59.

Geiger, Abraham. "Recension der Briefe über Judenthum (3)." Wissenschaftliche Zeitschrift für jüdische Theologie 3, no. 1 (1837): 74-91.

Geiger, Abraham. Über den Austritt aus dem Judenthume: Offenes Sendschreiben an Herrn. M. Maaß. Breslau: J. U. Kern, 1858.

Gottlieb, Michah. Faith and Freedom: Moses Mendelssohn's Theological-Political Thought. New York: Oxford University Press, 2011.

Gottlieb, Michah. Faith, Reason, Politics: Essays on the History of Jewish Thought. Brighton, MA: Academic Studies Press, 2013.

Gottlieb, Michah. "Oral Letter and Written Trace: Samson Raphael Hirsch's Defense of the Bible and Talmud." Jewish Quarterly Review 106, no. 3 (2016): 316-51.

Harris, Jay M. How Do We Know This? Midrash and the Fragmentation of Modern Judaism. Albany, NY: State University of New York Press, 1995.

Harvey, Warren Zev. "Hasdai Crescas and Moses Mendelssohn on Beliefs and Commandments." In Moses Mendelssohn: Enlightenment, Religion, Politics, Nationalism, edited by Michah Gottlieb and Charles H. Manekin, 79-89. Bethesda: University Press of Maryland, 2015.

Heschel, Susannah. Abraham Geiger and the Jewish Jesus. Chicago: University of Chicago Press, 1998.

Hirsch, Samson Raphael. Collected Writings. Edited by Marc Breuer, Jacob Breuer, Meta Bechhofer, and Elliot Bondi. 9 vols. New York: Feldheim, 1984-2012.

Hirsch, Samson Raphael. Gesammelte Schriften. Edited by Mendel Hirsch. 6 vols. Frankfurt am Main: J. Kauffmann, 1902-12.

Hirsch, Samson Raphael. Neunzehn Briefe über Judentum. 2nd ed. Frankfurt: J. Kauffmann, 1889.

Hirsch, Samson Raphael. Sefer Šemeš Marpe': še'elot u-tešuvot, hiddušei ha-Šas, iggerot u-mikhtavim. Edited by Eliyahu Meir Klugman. New York: Mesorah, 1992.

Hirsch, Samson Raphael. The Nineteen Letters about Judaism. Translated by Karin Paritzky. Edited by Joseph Elias. New York: Feldheim, 1995.

Jacobs, Louis. Principles of the Jewish Faith: An Analytical Study. London: Vallentine Mitchell, 1964.

Joël, Manuel. Zur Orientirung in der Cultusfrage. Breslau: Schletter’sche Buchhandlung, 1869.

Katz, Jacob. A House Divided: Orthodoxy and Schism in Nineteenth-Century Central European Jewry. Translated by Ziporah Brody. Hanover, NH: Brandeis University Press, 1998.

Katz, Jacob. Divine Law in Human Hands: Case Studies in Halakhic Flexibility. Jerusalem: Magnes Press, 1998.

Katz, Jacob. From Prejudice to Destruction: Anti-Semitism, 1700-1933. Cambridge, MA: Harvard University Press, 1980.

Katz, Jacob. "Orthodoxy in Historical Perspective." In Studies in Contemporary Jewry, Volume 2, edited by Peter Medding, 3-17. Bloomington: Indiana University Press, 1986.

Katz, Jacob. Tradition and Crisis: Jewish Society at the End of the Middle Ages. Translated by Bernard Dov Cooperman. Syracuse: Syracuse University Press, 2000.

Kayserling, Meyer. Moses Mendelssohn: sein Leben und seine Werke. Leipzig: H. Mendelssohn, 1862.

Kellner, Menachem. Dogma in Medieval Jewish Thought: From Maimonides to Abravanel. Oxford: Oxford University Press, 1986.

Kellner, Menachem. Must a Jew Believe Anything? 2nd ed. Oxford and Portland, OR: Littman Library of Jewish Civilization, 2006. 
Koltun-Fromm, Ken. Abraham Geiger's Liberal Judaism: Personal Meaning and Religious Authority. Bloomington: Indiana University Press, 2006.

Krone, Kerstin von der. "Jüdische Wissenschaft und modernes Judentum: eine Dogmendebatte." In Die "Wissenschaft des Judentums": Eine Bestandsaufnahme, edited by Thomas Meyer and Andreas Kilcher, 115-38. Paderborn: Wilhelm Fink Verlag, 2015.

Liberles, Robert. Religious Conflict in Social Context: The Resurgence of Orthodox Judaism in Frankfurt Am Main, 1838-1877. Westport, CT: Greenwood Press, 1985.

Mendelssohn, Moses. Gesammelte Schriften: Jubiläumsausgabe. Edited by Alexander Altmann et al. 25 vols. Stuttgart and Bad Cannstatt: Frommann-Holzboog, 1971-.

Mendelssohn, Moses. Jerusalem, or On Religious Power and Judaism. Translated by Allan Arkush. Edited by Alexander Altmann. Hanover, NH: University Press of New England, 1983.

Mendelssohn, Moses. Moses Mendelssohn: Writings on Judaism, Christianity, and the Bible. Translated by Curtis Bowman, Elias Sacks, and Allan Arkush. Edited by Michah Gottlieb. Hanover, NH: University Press of New England, 2011.

Mendelssohn, Moses. Moses Mendelssohn's Hebrew Writings. Translated by Edward Breuer. Edited by Edward Breuer and David Sorkin. New Haven: Yale University Press, 2018.

Mendes-Flohr, Paul R., and Jehuda Reinharz, eds. The Jew in the Modern World: A Documentary History. 3rd ed. New York: Oxford University Press, 2011.

Meyer, Michael. Response to Modernity: A History of the Reform Movement in Judaism. New York: Oxford University Press, 1988.

Meyer, Michael. "Universalism and Jewish Unity in the Thought of Abraham Geiger." In The Role of Religion in Modern Jewish History, edited by Jacob Katz, 91-107. Cambridge, MA: Association for Jewish Studies, 1975.

Philipson, David. The Reform Movement in Judaism. New York: Macmillan, 1907.

Plaut, W. Gunther. The Rise of Reform Judaism: A Sourcebook of Its European Origins. New York: World Union for Progressive Judaism, 1963.

Protokolle und Aktenstücke der Zweiten Rabbiner-Versammlung. Frankfurt, E. Ullmann, 1845.

Sacks, Elias. Moses Mendelssohn's Living Script: Philosophy, Practice, History, Judaism. Bloomington: Indiana University Press, 2017.

Sarna, Nahum M. Studies in Biblical Interpretation. Philadelphia: Jewish Publication Society, 2000.

Schorsch, Ismar. From Text to Context: The Turn to History in Modern Judaism. Hanover, NH: University Press of New England, 1994.

Schwarzschild, Steven. The Pursuit of the Ideal: Jewish Writings of Steven Schwarzschild. Edited by Menachem Kellner. Albany, NY: State University of New York Press, 1990.

Shapiro, Marc B. The Limits of Orthodox Theology: Maimonides' Thirteen Principles Reappraised. Oxford and Portland, OR: Littman Library of Jewish Civilization, 2004.

Silber, Michael. "Orthodoxy." In The Yivo Encyclopedia of Jews in Eastern Europe, edited by Gershon Hundert, 2:1292-97. New Haven: Yale University Press, 2008.

Speight, R. Marston. “Creeds: An Overview." In Encyclopedia of Religion, 2nd ed., edited by Lindsay Jones, 3:2052-54. Detroit: Macmillan 2004.

Steinheim, Salomon. Moses Mendelssohn und seine Schule. Hamburg: Hoffmann und Campe, 1840.

Williams, M.E. “Dogma." In New Catholic Encyclopedia, 2nd ed., edited by Thomas Carson, 1:81011. Detroit: Thomson/Gale, 2002. 